\title{
The performance of implementation movement restrictions during COVID-19 pandemic in West Sumatra and its impact
}

\author{
Purnawan $^{1 *}$ and Efendi Heru ${ }^{1}$ \\ ${ }^{1}$ Department of Civil Engineering, University of Andalas, Padang, Indonesia
}

\begin{abstract}
The COVID-19 outbreak is currently spreading to all regions of Indonesia. This virus was suspected to spread from Wuhan at the end of December 2019. Restrictions on people's movements are one of the government policies that aim to reduce the spread of COVID-19. To find out the performance of government policy, a study on the implementation of restrictions policy to prevent the spread of COVID-19 in West Sumatra has been conducted. This study used the before-after method as data analysis, then the data was examined using the Chi-Square test. Based on the results of data analysis, it was found that the movement of people after the implementation of restrictions movement policy was decreased significantly. The decrease in the need to leave the house was average $57.7 \%$, frequency leaving the house more than 5 times decreased by $80 \%$. Time of leaving the houses in the day, in the afternoon and at night decreased more than $50 \%$, the use of vehicle modes decreased by $14.9 \%$ and the number of people traveling outside the house decreased by $23.2 \%$. The performance of restrictions on people's movement policy in West Sumatra was still not optimal, because many people did not know the detail of policies.
\end{abstract}

\section{Introduction}

At present, all regions in Indonesia are still busy dealing with the COVID outbreak. This virus was suspected from Wuhan City China, the virus spread at the end of December 2019 [1]. COVID-19 at that time was known as pneumonia due to the novel coronavirus, or a new coronavirus that had never been found before. Wuhan has a transportation hub in the form of the Hankou train station. Every day, tens of thousands of Chinese citizens pass through this station. This station was the starting place for dozens of COVID-19 cases. One of the factors supporting the spread of COVID-19 is the high flow of travel in the context of the Chinese New Year. Hundreds of millions of Chinese citizens then traveled to visit relatives' homes. Mostly concentrated in Beijing, Shanghai, and Guangzhou. The flow of travel from Wuhan continues to increase. In early 2020, about seven million Wuhan residents traveled to various regions. Thousands of people are thought to have contracted COVID-19. When the Chinese government realized the risk of human-to-human transmission, the local spread of COVID-19 was already occurring in Shanghai, Beijing, and several other big cities. The government has also implemented lockdowns in several cities and restricted travel in China. However, the plague has already spread widely. Health Sector: Many people affected by COVID19 are scattered in various countries. At that time, the countries most affected by the pandemic were China, the USA, and Iran [2].

\footnotetext{
* Corresponding Author: purnawan@eng.unand.ac.id
}

In mid-January 2020, thousands of Wuhan residents were still traveling to cities in various countries. The first case appeared in Thailand. Indonesia also reported its first two cases in Depok. Three weeks later, the Figure soared to 514 cases with 49 deaths. Cases in Indonesia have increased significantly and this continues and spreads throughout Indonesia. The COVID-19 pandemic has created chaos in Indonesia. This pandemic has turned the stability aspect of the country into chaos. Starting from the economy, health, social, culture, and also transportation aspects. The Indonesian government has reviewed various policies to minimize the spread of the COVID-19 pandemic. Starting from examining citizens who have just traveled from abroad, carrying out travel restrictions, and imposing regional quarantine. Parmet. and Sinha [3] reveal the importance of quarantine and travel restriction to reduce the spread of COVID-19.

Regional quarantine is a government policy that aims to reduce the spread of COVID-19, so as not to be exposed to more positive victims. One implementation is to limit the movement of the community and the desire of the people to gather in a crowd. The community is not allowed to leave the house if there is no need for an emergency. Government policies are enforced in various regions in Indonesia, including West Sumatra province. This policy is part of a traffic management measure that is implemented by local government or local people. Traffic management itself is a process of regulating using transport system conditions to meet with required [4]. Tanariboon reveals that transport demand management 
can be implemented by utilizing all existing transportation facilities and means more efficiently, it can use regulation to minimize the use of vehicles [5], another type of transport demand management is using physical restriction, this can be implemented to obstruct the movement of vehicles to reduce congestion [6]. To reduce the spread of COVID-19, the Indonesian government finally implemented large-scale social restrictions (PSBB), this implemented depending on the facility and other resources of the city that is prepared. This restriction was implemented on an area suspected of being infected with COVID-19, this was conducted to prevent the possible spread of COVID-19 [7]. This policy is a combination of traffic management and quarantine scenario. This paper reveals the result of the implementation of several types of movement restrictions implemented by local government and local people in West Sumatra. Identifying people's movements before and during movement restrictions was conducted, then the impact of restriction movement is explained.

\section{Research Method}

This research was conducted based on the information obtained from the respondent that living in West Sumatra. The survey was carried out using an online system from 10 April 2020 until 20 June 2020, during this period, there are restriction movement policies in several cities. From the survey, 247 respondents have been collected. These respondents were obtained from a selected WhatsApp group, an online questionnaire was sent to several WhatsApp groups. The data collected include a profile of respondents, characteristics of movement restriction, and impact of its restriction movement. To obtain the impact of restriction movement, a comparison of people movement before COVID 19 epidemic and during COVID 19 epidemic was compared. Statistical analysis using the chi-square test was used to identify the difference between those conditions.

\section{Finding and Discussion}

\subsection{Characteristic of Respondent}

The result of the research is greatly influenced by the respondent characteristic, Tabel 1 below displays the characteristic of the respondent.

Table 1 indicates that the majority of the respondents are from West Sumatra, and most of them are from Padang (20\%), Padang is a city in West Sumatra that has the highest COVID-19 patient. Most of the respondent is active people that usually have activity outside the house. Based on information from respondents it is known that most of the cities in West Sumatra implement movement restriction, only $55 \%$ of respondents say that their city implements the movement restriction policy. At that time, positive COVID-19 patients still have not spread evenly at all cities in West Sumatra.
Table 1. The characteristic of respondents

\begin{tabular}{|c|c|}
\hline Characteristic & Percentage of respondent \\
\hline $\begin{array}{l}\text { The origin of the } \\
\text { respondent }\end{array}$ & $\begin{array}{c}\text { West Sumatra }(85.8 \%) \text {, Others } \\
(14.2 \%)\end{array}$ \\
\hline Gender & Male $(50.5 \%)$, Female $(59.5 \%)$ \\
\hline $\begin{array}{l}\text { Respondent of } \\
\text { district }\end{array}$ & $\begin{array}{c}\text { Padang }(20 \%) \text {, Padang } \\
\text { Pariaman }(1.4 \%) \text {, Pariaman } \\
\text { (1\%), Solok (2.4\%), Solok City } \\
\text { (2.4\%), Tanah Datar (30\%), } \\
\text { Padang Panjang (1.4\%), Agam } \\
\text { (3.8\%), Bukittinggi }(3.3 \%), \\
\text { Lima Puluh Kota }(1.4 \%), \\
\text { Payakumbuh (3.8\%), Sijunjung } \\
\text { (13.8\%), Sawahlunto }(2.4 \%), \\
\text { Pasaman (1.4\%), Pasaman } \\
\text { Barat (1.4\%), Dharmasraya } \\
\text { (1\%), Solok Selatan }(0.5 \%), \\
\text { Pesisir Selatan }(8.1 \%), \\
\text { Mentawai }(0.5 \%) \\
\end{array}$ \\
\hline Age & $\begin{array}{c}<20 \text { years }(5.7 \%), 20-29 \text { years } \\
(41.2 \%), 30-39 \text { years }( \\
26.5 \%), 40-49 \text { years }(8.5 \%) \\
>50 \text { years }(18 \%)\end{array}$ \\
\hline Education & $\begin{array}{c}\text { Primary School }(0.5 \%) \text {, Yunior } \\
\text { High School }(0.0 \%) \text {, Senior } \\
\text { High School }(17.5 \%) \text {, Diploma } \\
(10 \%) \text {, Bachelor }(62.6 \%), \\
\text { Master of Science }(9.0 \%), \\
\text { Doctoral }(0.5 \%) \\
\end{array}$ \\
\hline Occupation & $\begin{array}{c}\text { Government Official }(29.1 \%), \\
\text { Bussinessmen }(1.9 \%), \\
\text { Housewife }(6.7 \%) \text {, Student } \\
\text { (29.1\%), Retired }(2.4 \%) \text {, Others } \\
(31 \%)\end{array}$ \\
\hline $\begin{array}{l}\text { Implementation } \\
\text { movement } \\
\text { restriction in the } \\
\text { respondent area }\end{array}$ & Yes $(55 \%)$, No $(44.1 \%)$ \\
\hline
\end{tabular}

\subsection{Characteristic of Movement Restrictions During COVID-19 Pandemic}

\subsubsection{Quarantine and social restriction.}

During COVID-19 hits Indonesia, several movement restriction types were implemented by the local government or local people. At that time, local government officials and local people has limited knowledge about how COVID-19 spreads. To avoid COVID-19, some quarantine type has been implemented, Fig. 1 shows the type of quarantine experienced by the respondent in that area, then the type of social restriction implemented at the respondent area is shown in Fig. 2.

From Fig. 1, it is shown that the highest respondent experienced type quarantine is large scale social restriction, it is because the high sample respondent is from Padang, however, some people have experience house and district quarantine. During local government or local people implement quarantine to save the people from COVID-19, they implement social restrictions, this restriction to hamper people to leave a certain area. Fig 2 
shows the type of social restrictions experienced by respondents, the highest percentage is closing access in and out of district/city area, and other respondents did not know about those implementations of social restrictions.

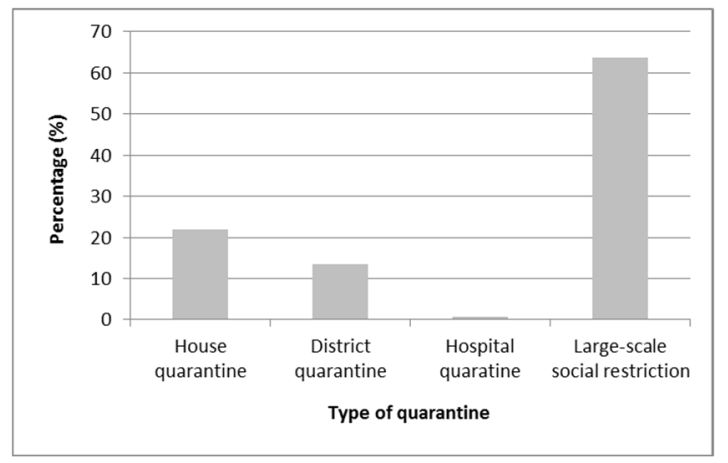

Fig. 1. Type of quarantine that known by respondent

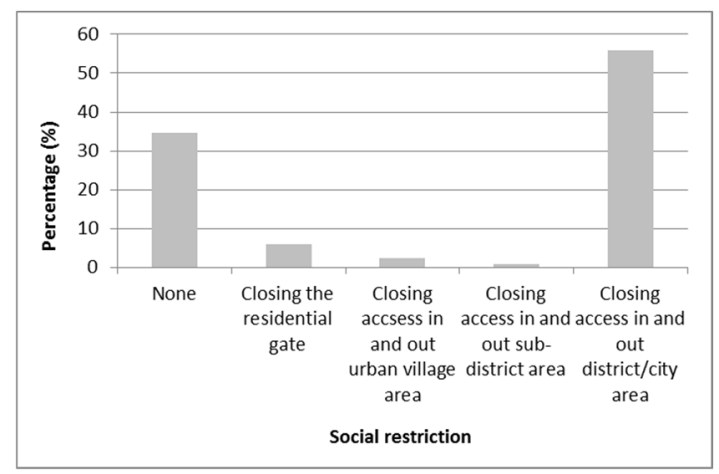

Fig. 2. Type of social restriction that implemented

From Fig. 1, it is shown that the highest respondent experienced type quarantine is large scale social restriction, it is because the high sample respondent is from Padang, however, some people have experience house and district quarantine. During local government or local people implement quarantine to save the people from COVID-19, they implement social restrictions, this restriction to hamper people to leave a certain area. Fig. 2 shows the type of social restrictions experienced by respondents, the highest percentage is closing access in and out of district/city area, and other respondents did not know about those implementations of social restrictions.

\subsubsection{Area restriction and limitation leaving the house.}

At the beginning of the COVID-19 spread, the local government and local people have implemented several policies without coordination with a higher level of government. Therefore, several types of restriction areas and time limitations to leave the house, Fig. 3 and Fig. 4 show the result of data analysis.

From Fig. 3, it is shown that restriction movement experienced by the respondent was implemented in district or city area, and in Fig. 4 is depicted that most respondent has the experience that there is no time limitation to leave the house $(75 \%)$, but there is an area that implemented time limitation to leave the house, this is about $30 \%$.

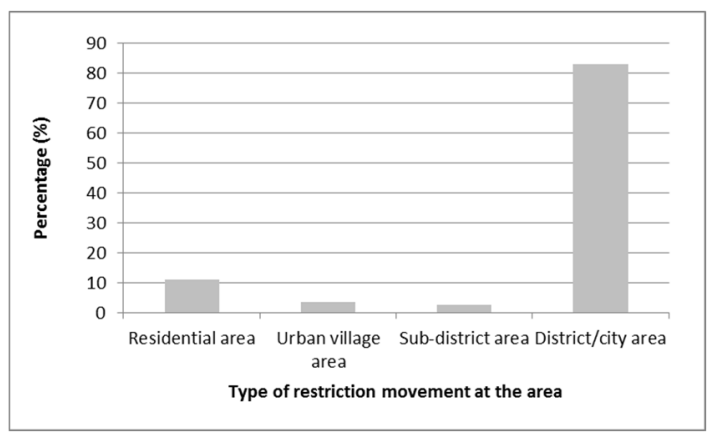

Fig. 3. Type of restriction movement at the area of respondent

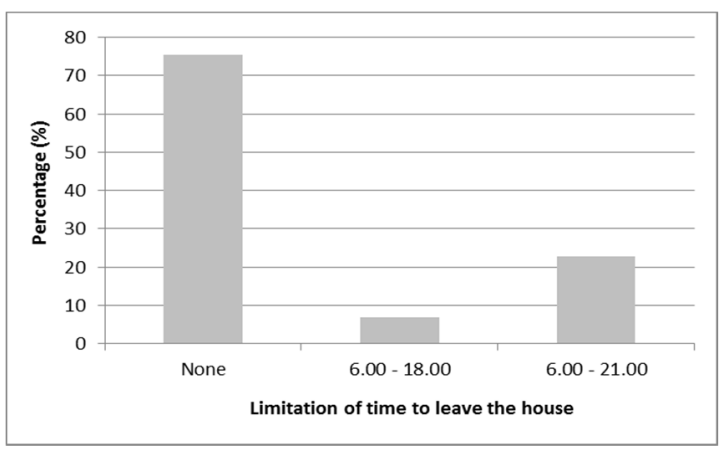

Fig. 4. Limitation of time to leave the house at a respondent area

\subsubsection{Socialization and sanction of movement restriction policy.}

Before the implementation of the restriction movement policy, there are socialization to the people. Fig. 5 and 6 shows the type of socialization and sanction to people who violate the policies

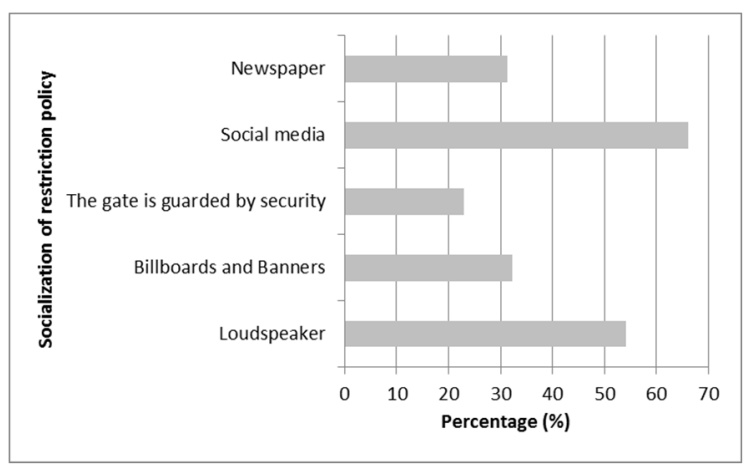

Fig. 5. Socialization of restriction policy that respondent known

From the information of respondents, most of them know the movement restriction policy from social media $(67 \%)$ and loudspeaker $(55 \%)$, the other know from the newspaper, billboard, and gate that guarded by security in 
Fig. 5, this means that people always have COVID information from social media. This data also indicates that most of the people did not know there is a sanction for the violator and most of the policies were implemented without sanction, this condition that affect movement restriction policies was ineffectively implemented.

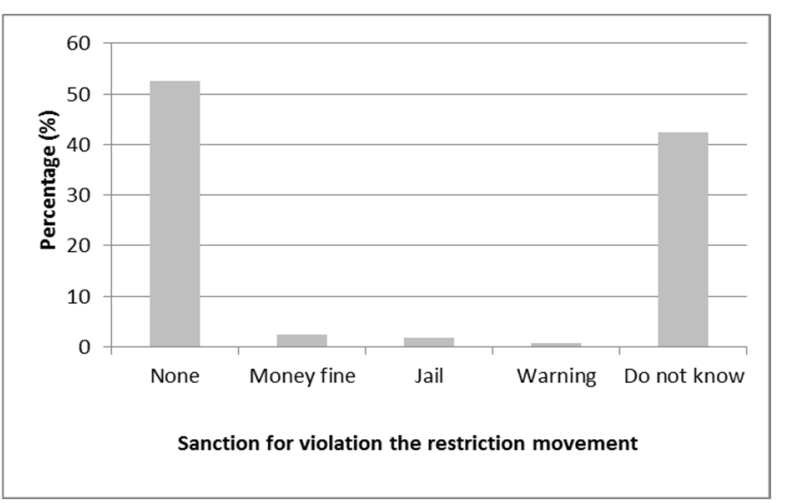

Fig. 6. The sanction for violation of restriction movement that respondent known

\subsection{Performance and Impact of Movement Restrictions During Pandemic COVID-19}

The government policy to reduce the spread of the pandemic COVID-19 has an impact on people's movement. The performance of movement restrictions is indicated by the condition people's movements before and during pandemic COVID-19 occur. Then, the impact of movement restriction policy is determined based on the value of percentage increase or decrease condition before and during pandemic COVID-19. Four variables have been analyzed for the impact of movement restriction policy, i.e. type of the need to leave the house, the use of transport mode, the frequency leaving the house, and the number of people leaving the house.

\subsubsection{Type of the need to leave the house}

The government has implemented the movement restriction policy, however, people still need to leave the house to fulfill the family need. Based on this condition, the type of people leaving the house before and during the COVID epidemic is identified. Fig. 7 show the different condition of people leaving the house for two conditions, and Fig. 8 indicates the impact of both condition that shown in the value of percentage decrease or increase.

Fig. 7 shows that the percentage of people leaving the house to fulfill daily need increase, the other type of need to leave the house decreased. This condition indicates that people obey the government policy, they stay at home and leave the house majority to buy necessities.

Based on the results of the Chi-Square test using $\alpha=$ 0.05 , the calculated Chi-Square value is 42.5 , this value is greater than the Chi-Square value from the table $(18,307)$, it can be concluded that Ho is rejected and $\mathrm{H}_{1}$ is accepted, meaning that there is a significant decrease in the needs to leave the house. Fig. 8 indicates that the percentage increase people leave the house to buy daily necessities is about $28 \%$, the high decrease is on the activity social gathering and recreation, it decreases about $100 \%$ and $90 \%$. This condition would affect the tourist business and social gathering facilities business, such as cafe, gathering room, restaurant, etc.

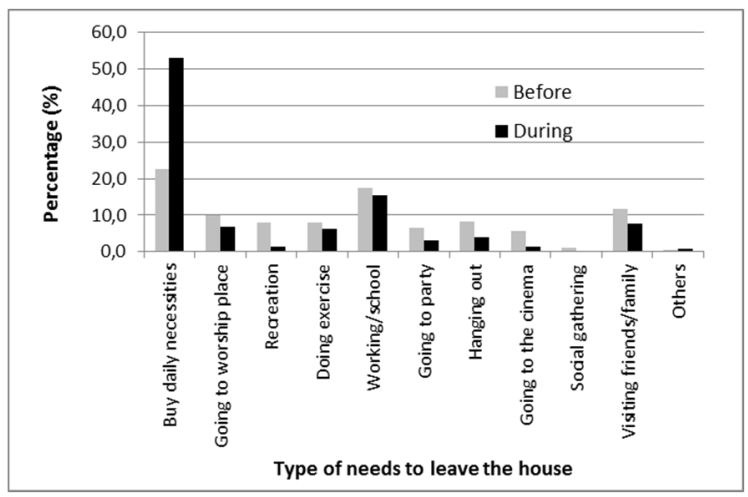

Fig. 7. Type of the need to leave the house before and during the COVID epidemic

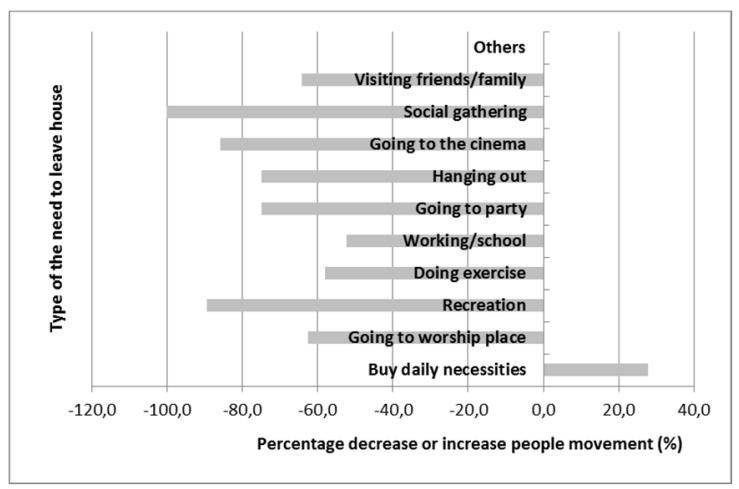

Fig. 8. Percentage decrease or increase the need to leave the house because of the COVID epidemic

\subsubsection{The use of transport mode}

During people leave the house, they use a transport mode, the transport mode that is used by people depending on the distance from the house. Fig. 9 give information on the condition of people using transportation mode before and during the COVID-19 epidemic, and Fig. 10 indicate the impact of both condition that is in the percentage decrease of increase of transport mode that used by people during the COVID-19 epidemic.

People tend to walk during the COVID-19 epidemic, if they should use the vehicle, they use the motorcycle, public transport, and car was avoided by people, this condition is indicated in Fig. 9. The impact of this condition is depicted in Fig. 10, it would decrease the use of public transport by about $66 \%$, and increase the use of motorcycles by $16 \%$, and increase people to walk by about $59 \%$. This condition will make it difficult for public transport divers and owners because their income reduces significantly. Chi-Square test has been conducted using $\alpha$ $=0.05$, the result of calculated Chi-Square value is 7.920, 
this value is greater than 7.779 the value from the table, it can be concluded that Ho is rejected and $\mathrm{H}_{1}$ is accepted, meaning that there is a significant difference the transport mode that used by people before dan during COVID-19 pandemic.

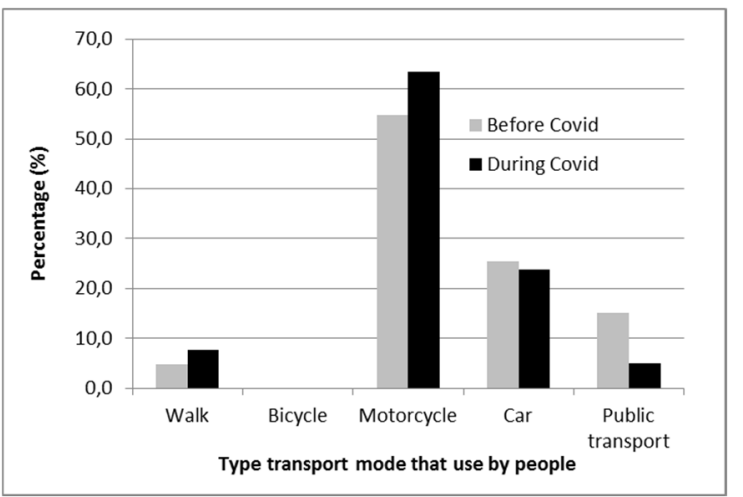

Fig. 9. The use of transport mode before and during the COVID epidemic

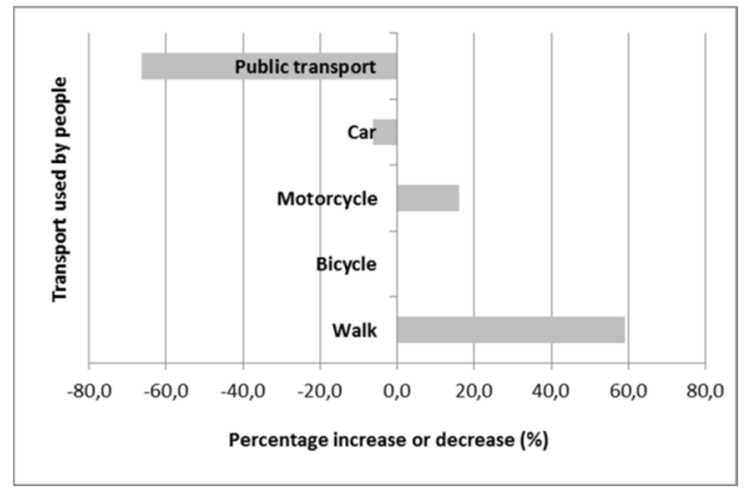

Fig. 10. Percentage decrease or increase the use of transport mode because of COVID epidemic

\subsubsection{The frequency leaving the house}

The performance of the movement restriction policy also could be identified from the frequency of people leaving the house before and during the COVID epidemic. The different number frequency of people leaving the house has been compared, the result is shown in Fig. 11. Then, the percentage difference between conditions before and during pandemic COVID-19 could be seen in Fig. 12.

Fig. 11 shows the reduction of frequency leaving the house, this is indicated that the frequency of leaving the house 1-2 times increase during the COVID-19 pandemic, and the frequency leaving the house more than 3 times/day decrease. Analysis using Chi-Square test with $\alpha$ $=0.05$, the calculated Chi-Square value is 35.438 , this value is greater than the Chi-Square value from the table (7.815), this can be concluded that Ho is rejected and $\mathrm{H}_{1}$ is accepted, there is a significant difference between the frequencies of the needs to leave the house before and during COVID-19. The impact of this condition is shown

In Fig. 12, the percentage decrease for leaving the house more than 4 times is $400 \%$, and the increase of leaving the house for 2 times or less was increased about $80 \%$.

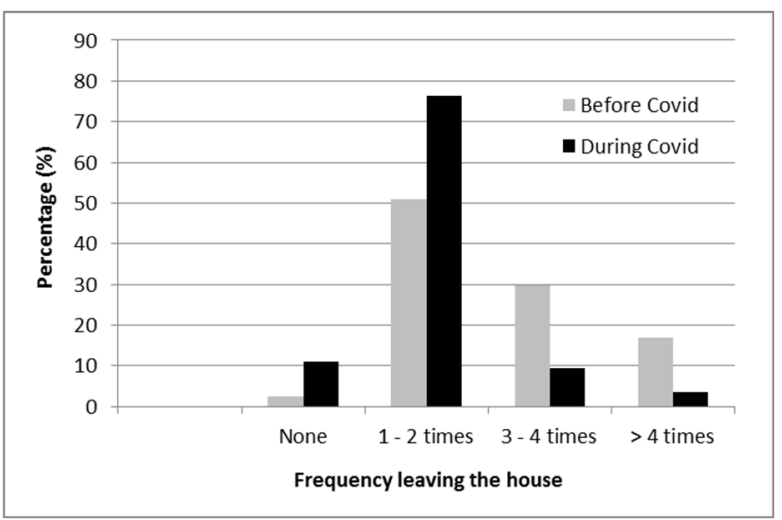

Fig. 11. The frequency of leaving the house before and during the COVID epidemic

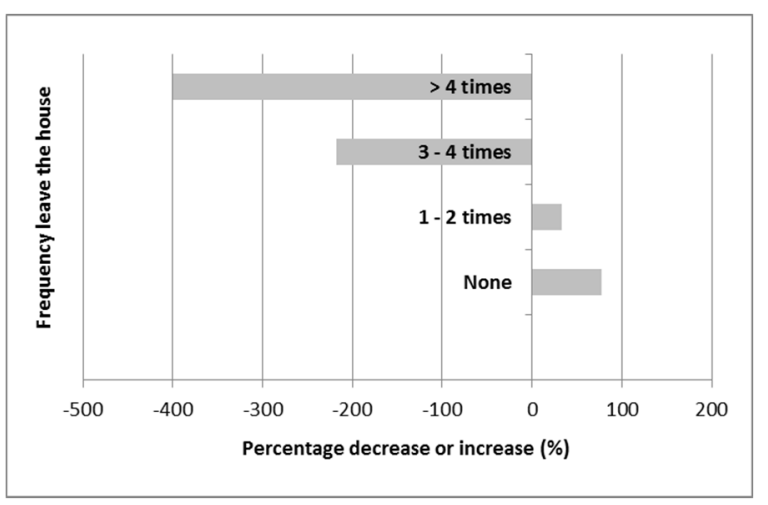

Fig. 12. Percentage decrease or increase the frequency because of COVID epidemic

\subsubsection{The number of people leaving the house}

To reduce the effect of spreading COVID-19, Government also produce a policy that the people were prohibited to near crowd people in the public area. Fig. 13 depicts the condition the number of people leaving the house before and during the COVID epidemic, for Fig. 14 indicates percentage increasing or decreasing the number

It is shown in Fig. 13 that during the COVID-19 pandemic, people tend to leave the house alone, the number of people leaving the house more than 2 was decreasing. Analysis Chi-Square test using $\alpha=0.05$, the calculated Chi-Square value is 6.947 , this value is less than the Chi-Square value from the table (7.815), this can be concluded that Ho is accepted and $\mathrm{H}_{1}$ is rejected, there is not a significant difference between the number of people leaving the house before and during COVID-19. The highest percentage decreasing number of people leaving the house for more than 5 people is about $66 \%$, and the percentage of people leaving alone increase by $40 \%$, this is shown in Fig. 14. This can be concluded that during the pandemic COVID-19 people obey Government policy. 
Although most people obey Government policies, however, the policy is still not optimum implemented. Several people are still violating Government regulations, some people still leave the house to public facilities that crowd by people, and there are still available people leave the house more than 2 people. Therefore, Government needs to improve the policy. The following policy should be implemented to increase the performance of movement restrictions in West Sumatra.

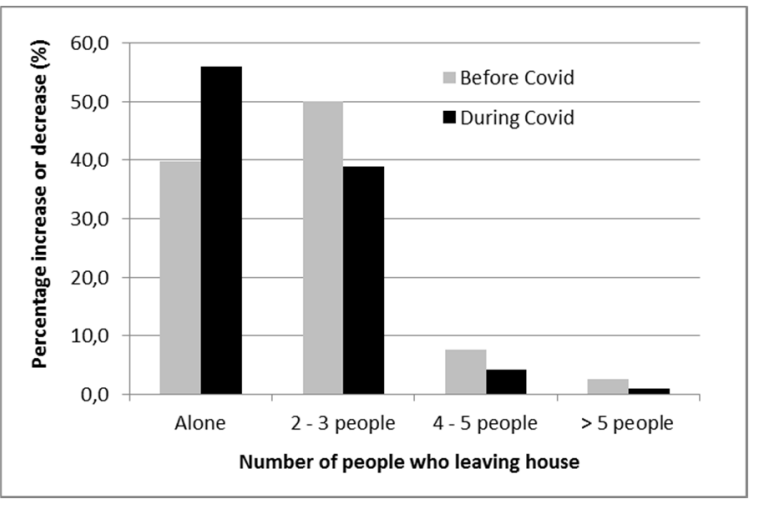

Fig. 13. The number of people who leaves the house before and during the COVID epidemic

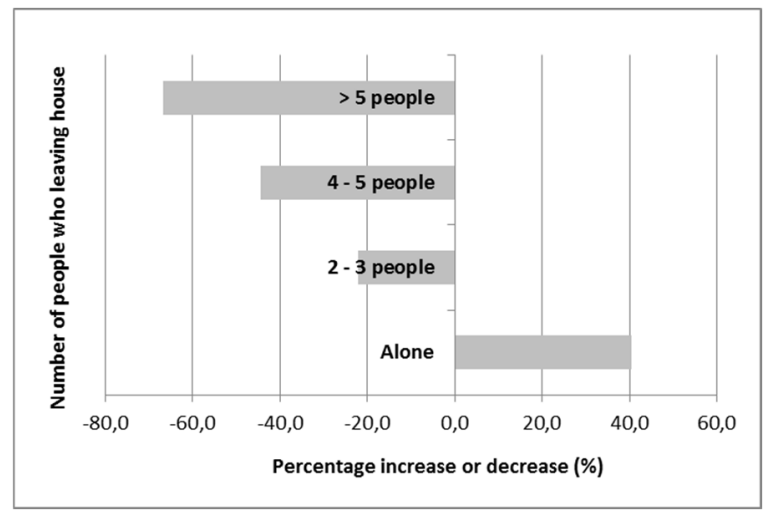

Fig. 14. Percentage decrease or increase the number of people who leave the house because of the COVID epidemic

Apply physical restrictions on guard by officers, so the movement of people is not easily carried out in the area. If the people have an emergency need to leave the area, that person must be free from COVID-19 or equipped with health protocol facilities.

- Control the time to leave the house for each area, so there are no crowds when meeting their daily needs in public facilities.
- Imposition of fines consistently and continuously by officers for violators.

\section{Conclusions}

Based on the analysis of respondent perception, it can be concluded that the movement of people after the implementation of restrictions on movement has decreased. This is because, before the implementation of movement restrictions, the people could fulfill their needs to leave the house freely, but after the movement restrictions were implemented by the Government or people, they are usually stayed at home and left the house only to fulfill basic needs such as buy daily food. This restriction movement policy has decreased by an average of $57.7 \%$ for all types of movement., The social gathering and tourism is the highest decrease. Statistical analysis using the Chi-square test shows that there is a significant decrease in all activity and all conditions. Although the people movement decrease, however, the performance of the people movement restriction policy is still not optimum, because people can leave the house and their area easily. Physical restriction with a guard by officers is required, control the time to leave the house should be implemented and the need of imposition the fines consistently and continuously by officers for violators.

The authors would like to thank the Engineering Faculty, University of Andalas. that supported this research, also Transportation laboratory assistants who help data collection.

\section{References}

1. Q. Li, X. Guan, , P. Wu, X. Wang, L. Zhou, Y. Tong, The New England Journal of Medicine (2020).

2. World Health Organization; Coronavirus (COVID19) (Accessed on 2 March 2020)

3. https://who.sprinklr.com/ (2020)

4. W. Parmet, and M .Sinha, The New England Journal of Medicine (2020).

5. A. A. Alamsyah, Traffic Engineering Revised Edition. UPT UMM; (2008)

6. Y. Tanariboon, Regional Development Dialogue 13 , 3 (1992).

7. J. Luk, Road, and Transport Research, 3 (1992).

8. Government Regulation No. 21 of 2020 about Large Scale Social Restriction in acceleration handling of coronavirus disease 2019 (COVID-19) 